AL IBTIDA: JURNAL PENDIDIKAN GURU MI (2019) Vol 6 (2): 144-158

DOI: http://dx.doi.org/ 10.24235/al.ibtida.snj.v6i2.4939

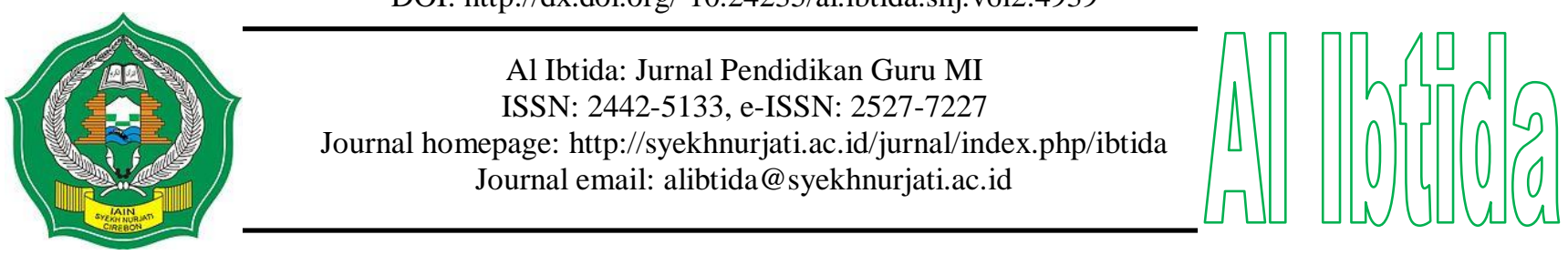

\title{
The Integration Model of Curriculum 2013 and Cambridge Curriculum in Elementary Schools
}

\section{Uswatun Hasanah*}

*Department of Madrasah Ibtidaiyah Teacher Education, Faculty of Tarbiyah and Teacher Training, Institut Agama Islam Negeri Tulungagung

Email: uswah2601@gmail.com

Received: August 08 ${ }^{\text {th }}, 2019$. Accepted: October $10^{\text {th }}, 2019$. Published: October $29^{\text {th }}, 2019$.

\begin{abstract}
This study aims to describe the integration model of 2013 curriculum and Cambridge curriculum as well as its implementation and the impacts of its integration in elementary schools. Involving an ICP class of Universitas Negeri Malang (UM) elementary laboratory school and a model class of Brawijaya Smart School elementary school, a qualitative case-study method and a multi cases design were employed in this study. The data were collected from observations, interviews, and documentations which then analyzed using an interactive analysis model. The result of the study shows that (1) the integration of 2013 curriculum and Cambridge curriculum in the Brawijaya Smart School elementary school uses a model of Sequenced Eye-glasses integration, while a Shared Binoculars Integration model is used in the UM elementary lab school; (2) The implementation of Sequenced Eyeglasses in the model class of the Brawijaya Smart School elementary school is conducted by compiling and teaching the materials from both curricula. Meanwhile, a Shared Binoculars Integration model in UM elementary lab school is implemented through teaching the 2013 curriculum thematically and the Cambridge curriculum separately. (3) The integration of 2013 curriculum and Cambridge curriculum enhances students' abilities in: a) English language; b) reasoning; c) creative thinking; and d) academic achievements.
\end{abstract}

Keywords: integrated curriculum model, 2013 curriculum, Cambridge curriculum.

\begin{abstract}
Abstrak
Penelitian ini bertujuan untuk mendeskripsikan model integrasi kurikulum 2013 dan kurikulum Cambridge beserta implementasinya, dan dampak integrasi tersebut pada sekolah dasar. Melibatkan satu kelas ICP (SD Laboratorium Universitas Negeri Malang) dan satu kelas model (SD Brawijaya Smart School), pendekatan kualitatif metode studi kasus dengan rancangan multikasus digunakan pada penelitian ini. Data diperoleh melalui observasi, wawancara, dan dokumentasi dan kemudian dianalisis dengan model analisis interaktif. Hasil penelitian menunjukkan bahwa (1) integrasi kurikulum di kelas Model SD Brawijaya Smart School menggunakan model integrasi Sequenced Eye-glasses, sedangkan model integrasi Shared Binoculars Integration digunakan di kelas ICP SD Laboratorium Universitas Negeri Malang; (2) Implementasi model Sequenced Eye-glasses dilaksanakan dengan menyusun materi dari dua kurikulum tersebut, dan mengajarkan materi yang berkaitan secara
\end{abstract}


bersamaan. Implementasi model Shared Binoculars Integration dilaksanakan dengan mengajarkan Kurikulum 2013 secara tematik dan Kurikulum Cambridge secara terpisah. (3) Integrasi kurikulum 2013 dan kurikulum Cambridge dapat meningkatkan a) kemampuan berbahasa Inggris; b) kemampuan dalam bernalar; c) kemampuan berpikir kreatif; dan d) prestasi akademik.

Kata kunci: model integrasi kurikulum, kurikulum 2013, kurikulum Cambridge.

\section{INTRODUCTION}

Education aims to improve the quality of human resources. They are not only limited to the cognitive aspect, but also the affective and psychomotor aspects. In the 21 st century, humans are required to have knowledge, creativity, innovation, and character. Based on the results of a research from one of educational innovation communities, it is believed that technological progress in the 21 st century opens opportunities as well as new challenges for all people. The world economic system transforms into an economic based system knowledge which is not based on natural resources. Countries that can develop and possess advanced knowledge will lead the world economy, despite of their limited natural resources (Wijaya, Sudjimat \& Nyoto, 2016). It can be understood that science is the basis of all sectors' development. Therefore, the education curriculum should be adapted to students' real life outside the school (Rahman, 2014).

As stated in the Law of Republic of Indonesia Number 20 year 2003 on national education system, the goal of Indonesia's national education is to shape students to have faith, religiosity, noble character, health, knowledge, capability creativity, independence, democracy, and responsibility. These goals can be achieved if education is carried out systematically to make students active in developing their potential, extending the spiritual strength, and expanding their horizons (Syaiful, 2018).

The description of the national education goals is internalized in the 2013 Curriculum competency standards. There are four core competencies that must be possessed by students, namely the spiritual core competence, social core competence, knowledge-based core competence, and skills-based core competence. The learning process cannot be delivered only through drilling or lecturing method. Therefore, the amount of time for every lesson in the 2013 curriculum is exceeding the previous curriculum. As stated by Abdullah, Abidin, \& Ali (2015), teachers should take a role in cultivating higher order thinking questions in the classroom while recognizing the difficulties faced by students in solving problems related to HOTS.

The data from observation showed that children categorized as fast learner can achieve the basic competencies quickly. They do not need a long time to do reasoning and problemsolving. When fast learners have completed the task, they will disturb the other students. Fonseca (2011) conveyed that children who have better academic achievement or called as 
special intelligent children need to get more treatment. If the special intelligent children are given similar treatment, they will face difficulties in making friends and become apathy.

Therefore, Brawijaya Smart School elementary school and Elementary Laboratory School State University of Malang compiled alternative strategies to facilitate fast learners. The strategy applied is the integration of national curriculum of 2013 and Cambridge curriculum. These two schools are not the first schools to implement integrated curriculum. In 2013 several schools in Indonesia held and exam of 28,000 participants with the Cambridge curriculum (Wardani \& Nugroho, 2016). However, the two schools in Malang were the first schools that shifted to integrate Curriculum 2013 and Cambridge curriculum from the school-based curriculum (KTSP).

Research on the integration of national and international curricula has been carried out by previous researchers. First, a study conducted by Purnomo (2015) on the integration of Cambridge curriculum and the 2013 curriculum in mathematics indicated that learning by using the integrated curriculum of Curriculum 2013 and Cambridge curriculum has an impact on better student learning outcomes. Another research on the development model of curriculum integration in international pilot schools Rusmilati (2007) showed that SMAN 3 Madiun was able to integrate grass-roots curriculum model and demonstration model. Based on the results of the two studies, it has not yet been found the integration model between 2013 curriculum and the Cambridge curriculum. This study is intended to provide an overview of the curriculum integration model in Brawijaya Smart School (BSS) Elementary School and Elementary Laboratory School State University of Malang (UM) and criticize the strengths and weaknesses in each school to be used as a reference for subsequent policymaking.

\section{METHODS}

This research is a qualitative research designed to describe the integration of the 2013 Curriculum and the Cambridge Curriculum in BSS Elementary School and Elementary Laboratory School UM specifically and clearly. The focus of this research is the integration model of the Curriculum 2013 and the Cambridge Curriculum. To answer how the integration of both curricula, researchers made in-depth and naturalistic observations. These activities emphasize that qualitative research must be carried out carefully, especially with crucial informants to create an atmosphere to support the success of data collection. Therefore, the data obtained becomes an authentic portrait of BSS Elementary Laboratory School UM. .

The research sites are BSS Elementary School and Elementary Laboratory School UM which are located in Malang and are acquiring A Accreditation. Therefore, the quality of both 
schools are excellent. However, each institution must have its own vision and mission as a character that distinguishes the direction of the education in each school.

Data about curriculum integration in BSS Elementary School and Elementary Laboratory School UM were collected by using interview, observation, and document analysis. The three data collection techniques are carried out in order to obtain comprehensive and accurate data. First, researchers conducted in-depth unstructured interviews. An unstructured interview is conducted without using interview guide questions while in-depth interview is carried out in a long time with the informants in the research site. In this study, unstructured and in-depth interviews were carried out by outlining the time and the number of informants needed in the research site.

Second, researchers did observations. Observation is a data collection technique done by systematic observing and recording of the phenomena under investigation. Researchers use observation techniques to complete and validate the results of interviews from informants who are likely not yet holistic or unable to illustrate the overall situations. This observation was carried out to obtain data on the implementation and the impacts of the integrated Curriculum 2013 and the Cambridge Curriculum. Third, researchers conduct a document analysis. The document analysis technique is used to collect data from non-human sources. The sources consisted of documents and records. Therefore, the documents collected in this study include Curriculum Structure documents, Syllabus, Lesson Plan, Cambridge Curriculum modules, photos during the lesson, observation transcripts, and interview transcripts.

The data analysis technique used in this study was an interactive model carried out continuously in each stage of the study until the data were saturated. The interactive data analysis techniques (Miles \& Huberman, 1994) employed in this study data collection, data reduction, a data display, and conclusion drawing /verification stages is presented below:

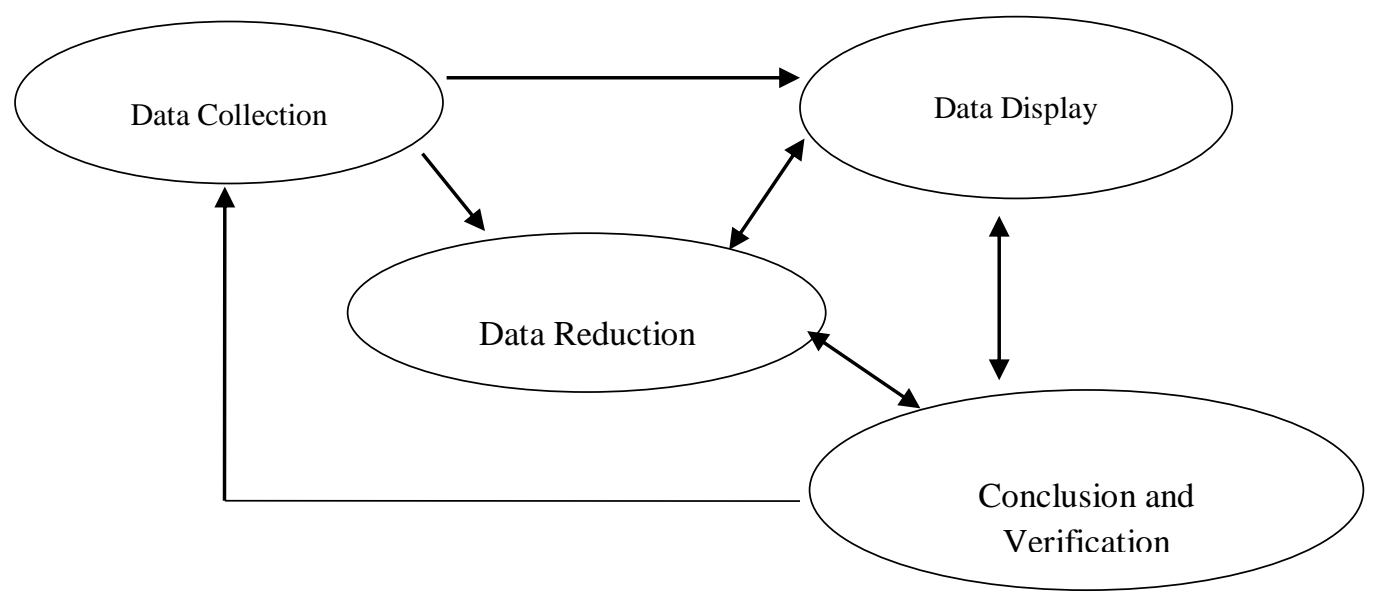

Figure 1. Interactive Data Analysis Technique Model 
To check the validity of the data, researcher used the criteria of credibility (trust) and transferability. Credibility is done by source and method triangulation techniques. Through triangulation technique, researchers can increase the credibility of interviews and document analysis results. Furthermore, the criteria for delinquency are carried out with detailed description techniques in which the researcher reports the results of the study as thoroughly and as carefully as possible.

\section{RESULTS AND DISCUSSION}

\section{Pattern of Integration of the 2013 Curriculum and the Cambridge Curriculum}

The curriculum in educational institutions must be well structured and programmed to be able to produce skilled and productive graduates. Curriculum Integration is a way to improve the quality of education. Therefore, Curriculum development is essential. Development of curriculum must consider the components of curriculum, namely objectives, materials, methods, students, educators, media, environment, and resources learning. The curriculum developed by BSS Elementary School and Elementary Laboratory School UM is an integrated curricula of Curriculum 2013 and the Cambridge curriculum. The integration of the two curricula can be completed since there are some similarities between Curriculum 2013 and the Cambridge Curriculum.

The integration curriculum also considered all aspects, specifically belief systems, value systems, needs systems which are integrated in the society. Fogarty (2009) stated that the concept of integrated curricula is intended to transform the learning into real-life experiences which can be applied in the future. Integrated learning is very compatible with the characteristics of young learners in primary school who tend to see things holistically (Wati, 2010).

As stated in the Mathematics, Science and English Cambridge framework that learning emphasizes the students to actively apply the theory, develop skills, and solve problems. Accordingly, the focus of learning not only to make students understand, but also to make students being creative and able to apply their knowledge. To achieve the learning objectives in the framework, it is necessary to have a good sense of reason and critical power.

Similarly, the Curriculum 2013 which proposes scientific approach in learning is assumed to be able to develop attitudes, skills and knowledge in a balanced way (Isno, 2018). Through the scientific approach, students will be more active in the classroom. The scientific approach includes five learning phase; 1) observing, 2) questioning, 3) associating, 4) experimenting, and 5) networking (Rudyanto, 2014). Observing, questioning, and exploring activities that run optimally will develop children's critical thinking. When children are able to associate and communicate well, then the children's reasoning skill will be increasingly sharpen. 
For that reason, there are characteristics of learning that are mutually sustainable between the 2013 Curriculum and the Cambridge Curriculum although the packaging is different.

The integration of Curriculum 2013 and the Cambridge Curriculum can be implemented with different models according to the situation and conditions in each school. BSS Elementary School and Elementary Laboratory School UM uses Fogarty's framework (2009) in designing the integration of the two curricula. However, the models used in the two schools are not identical, because the school conditions are different.

The 2013 Curriculum Integration and the Cambridge Curriculum in BSS Elementary School were not implemented in all classes. However, only model classes that use the integration of the two curricula. The other classes, called as regular classes, use Curriculum 2013. The term model classes is inspired by the existence of model schools as an example to the other schools. Model classes at BSS Elementary School are expected to be the role model for other classes to improve the quality of education and student competencies, especially national and international competencies.

Subjects in the model class are science, mathematics, English, Indonesian, civic education, Javanese, cultural arts and crafts, and physical education. Science, Mathematics, and English are taught using Cambridge course book, while the other subjects such as civic education, Javanese, arts, culture and crafts, as well as physical education, follow the Curriculum 2013. In detail, 14 hours lesson area located for Cambridge Curriculum subjects (4 hours lesson for Science, 6 hours lesson for Mathematics, and 4 hours lesson for English). On the other hand, 19 hours lesson are determined for all Curriculum 2013 subjects, both national and local content subjects, such as Javanese.

BSS Elementary School uses an integration model of sequenced eyeglasses. As explained in diagram 1 below:

\section{Sequenced Eye-glasses Description}

The topics are rearranged until they match with each other. The same ideas are taught together while maintaining the separate subjects.

The language teacher presents is a historical novel that depicts a specific period while the

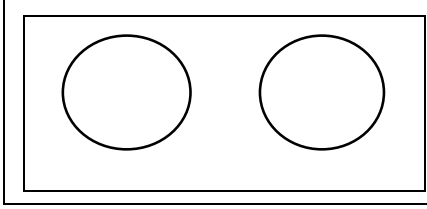
history teacher teaches the historical period the same (Drake, 2013).

Diagram 1. BSS Elementary School Curriculum Integration Model 
The diagram 1 is based on several research findings. First, the Curriculum 2013. Curriculum 2013 and Cambridge curriculum are related, mapped, sequenced and taught together in the subjects. As in Mathematics learning, the teacher outlines Mathematics Curriculum 2013 then teaches it simultaneously in Cambridge Mathematics learning. Second, although there is an integration in material learning that is compatible between the Curriculum 2013 and the Cambridge Curriculum, subjects in each curriculum are taught separately. For example, Civic Education, Indonesian Language, Culture and Arts, Physical Education refer to the Curriculum 2013 textbooks. Mathematics, Science, and English refer to the Cambridge Curriculum textbooks.

The Eye-glasses model Sequence used by BSS Elementary School has a number of advantages and disadvantages. Excess models Sequenced Eye-glasses are applied by BSS Elementary School gives a clear achievement on every subject. Teachers can identify learning outcomes in each subject easily. However, there are some drawbacks need to be followed up in Brawijaya Smart School Elementary School. There are some drawbacks of the curriculum integration model in Brawijaya Smart School Elementary School. First, Curriculum 2013 subjects were taught separately which cause students to lack of holistic knowledge. Holistic knowledge is knowledge built from a variety of knowledge sources without any subject restrictions. Therefore, if each subject is taught separately, students will find it difficult to link a problem with various disciplines. Second, since the implementation of Curriculum 2013 is not taught thematically, in evaluation session the teachers in BSS Elementary School use their own evaluation questions to find out students' progress in learning. Evaluations like this can measure the students' ability in the classroom but cannot measure the students' ability compared to other classes in the Curriculum 2013 standards. Therefore, to achieve relevant curriculum integration, it needs an evaluation and follow-up on the weakness of curriculum integration in the first year.

Different from BSS Elementary School, Laboratory Elementary School UM uses the term ICP (International Class Program) for classes which integrate Curriculum 2013 and the Cambridge Curriculum. The 2013 curriculum and the Cambridge curriculum in the ICP class are integrated into several hours of study. For lower classes, namely grades 1-3, the content of Curriculum 2013 are taught in 14 hours lesson each week with 35 minutes for every lesson hour. On the other hand, the material content included in the Cambridge Curriculum is 12 hours of study. The hours are divided into three subjects, namely, four hours for Science, four hours for English and four hours for Mathematics.

Therefore, the bilingual class for grade 1-3 go home at 11.15, the ICP class go home at 12.25 (every Monday-Thursday). The total number of lesson hours in grade 1 and 2 ICP for one week are 44 lesson hours. This amount of time has met the Minister of Education and Culture's 
regulation that the learning burden of primary schools/ madrasah ibtidaiyah students in one week must reach 30 lesson hours for grade I and 32 lesson hours for grade 2 students.

Learning in the Curriculum 2013 is using thematic books from the government, while in Cambridge Curriculum learning students use the Cambridge manual / module. The integration between the 2013 curriculum and the Cambridge curriculum lies in the content of the material delivered. The contents of the curriculum 2013 material are internalized in the text in each Cambridge module unit, in Mathematics, Science or English. So that the text in the Cambridge module is adjusted to the contents of the Curriculum 2013.

Thus, referring to the curriculum structure, module design, and learning described earlier, it can be concluded that the ICP classes use the integration of Curriculum 2013 and the Cambridge Curriculum. The existence of the attachment of Curriculum 2013 and Cambridge Curriculum in curriculum structure, materials, and learning shows that the 2013 curriculum integration model and the Cambridge Curriculum in the Elementary Laboratory School UM use the model shared binoculars. The more explanation is presented below.

Shared Binoculars Description

Planning and teaching takes place in two disciplines where overlapping concepts or ideas emerge when organizing elements.

Science and Mathematics Teachers use data collection, and chart making as shared concepts that the team can teach (Drake, 2013).

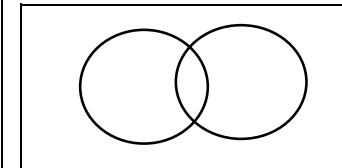

Diagram 2. Elementary Laboratory School UM Curriculum Integration Model

Shared binoculars (joint binoculars) is a model of curriculum integration by integrating two subjects, but there are concepts or skills complementary. Learning using the shared binoculars model (binoculars together) means that each discipline is taught in a different time but there is an integration between one another. This opinion is in accordance with the real conditions of the integration of curriculum 2013 and the Cambridge curriculum at Elementary Laboratory School UM.

From the integration model used, there are several advantages and disadvantages. The advantages of the Shared Binoculars Integration model in Laboratory Elementary Schools State University of Malang is that students can understand the correlation of material from each curriculum as they are not separated. What students understand in the Curriculum 2013 can be strengthened in the Cambridge Curriculum, for the materials are the results of the integration 
between two curricula. However, it should be noted that there are some disadvantages of the Shared Binoculars integration model. It is possible to have overlapping material contained in Curriculum 2013 and the Cambridge Curriculum. Therefore, teachers need to make a list of Curriculum 2013 and the Cambridge Curriculum materials to avoid repetition.

\section{The Implementation of Curriculum 2013 and the Cambridge Curriculum Integration}

The implementation of Curriculum 2013 and the Cambridge Curriculum in BSS Elementary School and Elementary Laboratory School UM is based on Renzulli (1977) concept about special intelligent children. Although there is no ideal way to measure special intelligence students, there are two forms of intelligence, namely schoolhouse intelligence and creative/productive intelligence (Supriyanto, 2012). Schoolhouse intelligence is related to students' IQ. To find out special intelligent children from schoolhouse type is to do an IQ test. On the other hand, creative/productive intelligence is more difficult to measure because its assessment is on how high the creativity of students in creating a product. Based on these two kinds of intelligence, the focus of the curriculum integration program in BSS Elementary School and Elementary Laboratory School UM is schoolhouse intelligence

To find out students' schoolhouse intelligence, both schools do a placement test in determining the students who can learn by using the national curriculum and the international curriculum. The placement test at BSS Elementary School consists of a literacy test, a study readiness test, and an English proficiency test. Whereas the placement test at Elementary Laboratory School UM consists of a written test, an English interview, and a creativity test.

Although the implementation of the placement test is different, both have similar goals, which is providing special services to special intelligence children. Fonseca (2011) argued that children who have better academic abilities or special intelligence ones need to acquire more treatment since they will encounter difficulty in establishing relationship with peers and become apathy. In more detail, Renzulli (1977) classified special intelligence children in three groups, namely children who have above average abilities, children who have high creativity, and children who have high task commitment. Those classifications became the background of curriculum development in BSS Elementary School and Elementary Laboratory School UM.

The implementation of the integration of Curriculum 2013 and the Cambridge Curriculum with sequenced eyeglasses model in BSS Elementary School can be seen from the time table (lesson schedule) and activities learning. The time table that has been compiled in this school indicated that the subjects of Curriculum 2013 and the Cambridge Curriculum are taught in separate time allocations except for subjects that have been covered in the Cambridge Curriculum, they are no longer taught in the 2013 Curriculum. Therefore, all subjects are taught 
separately. Civic education, Indonesian, and Arts and Culture subjects are taught using different textbooks based on the core competence and basic competence of Curriculum 2013 and using Indonesian. For the Cambridge curriculum, the subjects are taught separately by using the learners' book.

The implementation of the curriculum in BSS Elementary School that teaches content subject separately is not in accordance with the concept of the 2013 curriculum theoretically. As explained by Hajar in Mulyadin (2016), the concept of thematic integrated learning is using themes to integrate several subjects so that it can provide meaningful experiences to students.However, BSS Elementary School has developed a strategy to provide students with relevant materials in learning process. The learning activities begin with greeting, asking questions, and giving apperception about what will be learned. Furthermore, the teacher asks students to make observations both through images and objects around them related to the materials learned. The teacher gives questions to students to stimulate students' critical thinking and ask what the students want to know.

From this questioning activity, the teacher explores student understanding by giving opportunity for students to answer their friends' questions. The teacher also provides reinforcement material that has a correlation with other subjects. The implementation of Cambridge Curriculum is actually not much different from Curriculum 2013. The teacher continues to carry out the opening activities namely greetings, and apperception. However, at the core activity the teacher starts the explanation by asking students to read the text. Reading the text of materials being learned give students and exposure to read in English, and recognize and understand English vocabulary. After that, students work on the worksheet available in each chapter.

For materials that have correlation with 2013 Curriculum, the teacher does the material mapping first. Even though science and mathematics are not delivered in the curriculum 2013, the material content is still conveyed through learning the Cambridge Curriculum material. As an example, in the material of number line, the teacher enriches science by adding material about adding numbers such as $+1,+2,+3,+4,+5,+6$, multilevel adding numbers, and double adding numbers in the curriculum 2013. Although the student book from curriculum 2013 is not given to students, but the material content can still be delivered.

On the other hand, the Integration of the 2013 Curriculum and the Cambridge Curriculum in Elementary Laboratory School UM is located in the subject matter / sub subject. Before compiling the Cambridge module, the drafting team mapped the core competencies and basic competencies of the 2013 Curriculum 2013 so that they could be included in the Cambridge material unit. The subtopics are included in the text in each Cambridge unit. 
Although the learning in Curriculum 2013 and the Cambridge Curriculum is implemented separately, the connection between Curriculum 2013 and the Cambridge Curriculum can be taught in the text. In practice, learning in ICP classes is adjusted to the guidelines of each curriculum. In implementing curriculum 2013, the teacher used thematic learning with a scientific approach that referred to the teacher's handbook and student handbook.

Furthermore, in implementing the Cambridge curriculum, the teacher uses the teachermade module by referring to the Cambridge framework. Thematic learning in Elementary Laboratory School UM is taught with a series of learning activities, including opening, main and closing activities. The opening activity is accomplished by greetings and giving apperception. In the main activities teachers use scientific approach. The scientific approach is internalized in the 5 steps of learning, namely observing, asking, exploring, associating and communicating. This is consistent with the learning characteristics of curriculum 2013 which uses a scientific approach with five steps of learning. The five learning steps are observing, asking, exploring, associating and communicating (Permendikbud, 2016). While in the closing activity the teacher and students pray together and say goodbye.

In learning Mathematics, Science, and English in Cambridge Curriculum, teachers use the Cambridge modules and systematic learning of the Cambridge curriculum. Every Cambridge module unit starts with text and followed by the materials and worksheets. Implementation of the Cambridge Curriculum consists of three steps of learning, namely reading, listening to teacher's explanation and doing worksheets. At the beginning of learning, it always starts with reading activities, continues with understanding the material, and then doing the practice exercises. The purpose of learning the Cambridge Curriculum is not only to make students understand, but also to make students able to apply their understanding and solve the problems. As explained in the framework of the Cambridge Curriculum presented in table 1 below.

Tabel 1. Learning Objectives of Cambridge Curriculum

\begin{tabular}{|c|c|c|c|}
\hline No & Subject & Achievement & Cognitive \\
\hline & & Learning Objectives & (According to Bloom's Taxonomy) \\
\hline 1 & Mathematics & $\begin{array}{l}\text { Students are able to do problem } \\
\text { solving from number material, } \\
\text { geometry, measurement, and data } \\
\text { processing (Widjanarko, 2018) }\end{array}$ & $\begin{array}{l}\text { Problem solving according to } \\
\text { Bloom's taxonomic is thinking } \\
\text { ability which lies in cognitive ability } \\
\text { to analyze (C4) }\end{array}$ \\
\hline 2 & Science & $\begin{array}{l}\text { Students can conduct scientific } \\
\text { research up to the stage of data } \\
\text { analysis of biological, physical } \\
\text { and chemical material (Board \& } \\
\text { Cross, 2014). }\end{array}$ & $\begin{array}{l}\text { The ability to analyze according to } \\
\text { Bloom's taxonomy is the 4th } \\
\text { cognitive level (C-4). It is related to } \\
\text { cognitive processes of giving } \\
\text { attributes and organizing. }\end{array}$ \\
\hline 3 & English & $\begin{array}{l}\text { Students are able to communicate } \\
\text { effectively and think critically on } \\
\text { phonetic material, spelling }\end{array}$ & $\begin{array}{l}\text { Based on taxonomy of Bloom's } \\
\text { thinking framework, communication } \\
\text { skills are included in the framework }\end{array}$ \\
\hline
\end{tabular}


vocabulary, grammar and English of applying (C3). While critical punctuation (Budgell \& Ruttle, thinking includes evaluating 2014) cognitive ability (C5) which includes the process of checking and criticizing.

Therefore, the use of instructional design and integration of Curriculum 2013 and Cambridge Curriculum should continue to be refined. Students studying with a national standard curriculum and an international standard curriculum are expected to have high order thinking skills. Higher-order thinking skills can be familiarized through learning activities (Fitriani, Suryana, \& Hamdu, 2018). Learning activities need to be more varied in order to improve students' cognitive abilities at a higher level, namely applying, analyzing, evaluating, and creating. Implementation of Cambridge Curriculum Integration will be paramount if the planning process is also carried out maximally. The planning includes socializing, training on curriculum to be implemented, and planning of support systems such as facilities, infrastructure, human resources and financial resources.

\section{The Impact of Integration of Curriculum 2013 and Cambridge Curriculum}

The Implementation of integrated Curriculum 2013 and Cambridge Curriculum in BSS Elementary School and Elementary Laboratory School UM has a positive impact. The impacts from the implementation of the integration of Curriculum 2013 and Cambridge Curriculum are presented below.

a. Improve Students' English Ability

Learning that uses integration of Curriculum 2013 and the Cambridge Curriculum have a high potency of English use since teachers always try to communicate in English. In addition, the goals of the Cambridge Curriculum are to develop speaking, listening, reading, and writing skills in learning English. The framework has been developed in conjunction with Cambridge English Assessment and is based on the Common European Framework of Reference (CEFR), which is used throughout the world to map student progress in English (Diocolano \& Latifah, 2019). The integration of the 2013 curriculum and the Cambridge curriculum makes students have good English skills in speaking, listening and reading.

b. Build Reasoning

The integration of Curriculum 2013 and Cambridge Curriculum can build students' reasoning as the characteristics of the Cambridge curriculum encourages students to get involved intellectually and socially (Sari \& Olensia, 2017). The process of thinking becomes very important rather than referring to the results. The Cambridge curriculum emphasizes the children's ability to do problem solving. Mathematics in Cambridge curriculum has five contents 
namely, numbers, geometry, measurement, data processing, and problem solving. Problemsolving must be in all four previous material. Through problem solving students will be able to use techniques, skills and application of a concept. Based on these explanations, it is clear that all subjects, specifically Mathematics, is taught with the concept of problem solving. Therefore, the knowledge acquired is more applicable and students become skillful in solving a problem.

c. Foster Students' Creative Thinking Ability

Implementing the Cambridge Curriculum and Curriculum 2013 enables students to think creatively. The ability to think creatively according to Ikasen in Mahmudi (2010) is an idea construction process that emphasizes on fluency, flexibility, authenticity, and detail. According to Anwar, Shamim-ur-Rasool, and Haqq (2012), creative thinking is a new way of seeing and doing something that contains four aspects such as fluency, flexibility), authenticity, and elaboration. The ability to think creatively is proven by students works in the Model and ICP classes, such as making poetry, making picture stories, making batik, making movements from songs, and being creative in solving problems presented in essay about Mathematics.

d. Improve Students' Achievement

Implementing the integration of the Cambridge curriculum and Curriculum 2013 has a positive impact on students. One of the impacts of integrating both curricula is the increasing of students' academic achievement. The improvement of academic achievement is affected by the use of various learning materials and students centered learning approach. Students are actively participate in class to create ideas to solve problems. The ability to think creatively can improve student academic achievement as well. Wang (2011) suggested that the ability to think creatively built in the Cambridge curriculum would be positively correlated with student learning achievement.

Nafisah's research (2018) showed that the Cambridge curriculum influences students' learning outcomes greatly. Students who learn by using the integrated national and international curricula will have a more complex and directed mindset. Moreover, the findings are strengthened by the results of Purnomo's research (2015) which indicated that the integration of curriculum 2013 and the Cambridge curriculum facilitate students to eliminate the limitations of concept in each subject. Students can identify what is in their environment, make observations or even conduct experiments to make meaningful learning. According to Ausabel in Murfiah (2017), learning takes place in a meaningful process of relating new events or items to existing cognitive concepts or propositions. It is supported by the excessive students' achievements in the model class or the ICP class. The achievement can be winning Mathematics and Natural Sciences Olympiad, Spelling Bee and Emerald Olympics. 


\section{CONCLUSION}

Referring to the results of research and discussion, it can be concluded that integration pattern of Curriculum 2013 and Cambridge Curriculum in BSS Elementary School uses the Sequenced Eye-Glasses model. The model is implemented by arranging materials per subject in each curriculum based on grade levels, the similar or interrelated material is taught simultaneously. The Elementary Laboratory School UM uses Shared Binoculars Integration model. The model is implemented by teaching Curriculum 2013 thematically and the Cambridge Curriculum separately for each subject. The impact of the integration of the 2013 Curriculum and Cambridge Curriculum integration can improve students' abilities on English, reasoning, and creative thinking, and foster students' academic achievement. Therefore, the integration of the two curricula is relevant to the demand of $21^{\text {st }}$ Century skills.

\section{REFERENCES}

Abdullah, A. H., Abidin, N. L., \& Ali, M. (2015). Analysis of Students' Errors in Solving Higher Order Thinking Skills (HOTS) Problems for the Topic of Fraction. Asian Social Science, 11(21), 133-142.

Anwar, M., Shamim-ur-Rasool, S., \& Haq, R. (2012). A Comparison of Creative Thinking Abilities of High and Low Achievers Secondary School Students. International Interdiciplinary Journal of Education, 1(217), 1-10.

Board, J., \& Cross, A. (2014). Cambridge Primary Science Framework. Cambridge: Cambridge University Press.

Budgell, G., \& Ruttle, K. (2014). Penpals at Home: Getting Ready for Handwriting. Cambridge University Press.

Diocolano, N., \& Nafiah, N. (2019). Implementasi Kurikulum Cambridge di Sekolah Dasar. Pemikiran dan Pengembangan Sekolah Dasar, 7(1), 38-45.

Drake, S. M. (2013). Menciptakan Kurikulum Terintegrasi yang Berbasis Standar. Jakarta: PT Indeks.

Fitriani, D., Suryana, Y., \& Hamdu, G. (2018). Pengembangan Instrumen Tes Higher-Order Thinking Skill pada Pembelajaran Tematik Berbasis Outdoor Learning di SD. Pedadidaktika, 5(1), 252-262.

Fogarty, R. (2009). How to Integrate the Curricula. USA: Corwin Press.

Fonseca, C. (2011). Emotional Intensity in Gifted Students, Helping Kids Cope with Explosive Feelings. Waco Texas: Prufrock Press.

Isno. (2018). Model Adopsi Daptasi Kurikulum 2013 dan Cambridge University bagi Madrasah. PROGRESSA (Jurnal of Islamic Religious Instruction), 2(2), 17-26.

Mahmudi, A. (2010). Mengukur Kemampuan Berpikir Kreatif Matematis. Konferensi Nasional Matematika XV UNIMA. Manado: UNIMA.

Miles, M. B. \& Huberman, A. M., (1994). Qualitative data analysis: An expanded sourcebook. SAGE. 
Mulyadin. (2016). Implementasi Kebijakan Pembelajaran Tematik Terpadu Kurikulum 2013 di SDN Kauman 1 Malang dan SD Muhammadiyah 1 Malang. Edutama, 3(2), 31-48.

Murfiah, U. (2017). Model Pembelajaran Terpadu di Sekolah Dasar. Pesona Dasar,1(5), 57-69.

Nafisah, N. F. (2018). Implementasi Kurikulum Cambridge di Sekolah Dasar Internasional Al Al-Abidin Surakarta dan Sekolah Dasar Integral Walisongo Sragen. Profetika (Jurnal Studi Islam),19(2), 154-162.

PERMENDIKBUD. (2016). Standar Proses. PERMENDIKBUD RI No. 22 Tahun 2016. Indonesia

Purnomo, M. (2015). Integrasi Kurikulum Cambridge dalam Kurikulum 2013 Pada Pelajaran Matematika Sekolah Menengah Pertama. Prosiding Konferensi Nasional Penelitian Matematika dan Pembelajarannya. Surakarta: Universitas Muhammadiyah Surakarta.

Rahman, K. (2014). Pengembangan Kurikulum Terintegrasi di Sekolah/ Madrasah. Jurnal PAI (J-PAI), 1(1), 13-48.

Renzulli, J. (1977). The Enrichment Triad Model: Aguide for Developing defensible Programs for The Gifted. Manfield Center. CT: Creative Learning.

Rudyanto, H. E. (2014). Model Discovery Learning dengan Pendekatan Saintifik. Premiere Educandum, 4(1), 4-48.

Rusmilati, A. (2007). Model Kurikulum Integrasi pada Rintisan Sekolah Bertaraf Internasional di SMA Negeri 3 Madiun. Doctoral dissertation, Malang: Sekolah Pascasarjana Universitas Muhammadiyah Malang.

Sari, R. K., \& Olensia, Y. (2017). Potret Cambridge Advanced (Chemistry As and A Level) di Sekolah Mutiara Harapan Riau Tahun Ajaran 2015/2016. Jurnal Pendidikan Kimia, 1(1), $12-21$.

Supriyanto, E. (2012). Pengembangan Kurikulum Pendidikan Cerdas Istimewa. Yogyakarta: Pustaka Pelajar.

Syaiful, A. (2018). Peningkatan Mutu Pendidikan melalui Implementasi Kurikulum Terpadu di Sekolah Menengah atas Pesantren Al-In'Am Banjar Timur Gapura Sumenep. Kariman, 6(1), 1-20.

Wang, A. Y. (2011). Contexts of Creative Thinking: A Comparison on Creative. Journal of International and Cross-Cultural Studies, 2(1), 56-68.

Wardani, H., \& Nugroho, F. D. (2016). Intgerasi Kurikulum Nasional dan Cambridge Curriculum pada Mata Pelajaran Bahasa Inggris. The Curriculum Journal, 9(2), 666-679.

Wati, U. A. (2010). Pengembangan Multimedia Pembelajaran untuk Mata Kuliah Pembelajaran Terpadu. Penelitian Ilmu Pendidikan, 1(1), 2-11.

Widjanarko, J. (2018). Implementasi Kurikulum Cambridge dalam Pembelajaran Matematika. JPGSD, 6(6), 1030-1039.

Wijaya, E. Y., Sudjimat, D. A., \& Nyoto, A. (2016). Transformasi Pendidikan Abad 21 Sebagai Tuntutan Pengembangan Sumber Daya Manusia di Era Global. Prosiding Seminar Nasional Pendidikan Matematika (hal. 263-278). Malang: Universitas Kanjuruhan Malang 